\title{
An Empirical Study of the Relationship between Islamic Modes of Finance and Financial Intermediation
}

\author{
Hafnida Hafnida ${ }^{1}$, Selamah Maamor ${ }^{1} \&$ Hussin Abdullah $^{1}$ \\ ${ }^{1}$ Islamic Business School, Economics Building, Universiti Utara Malaysia, Malaysia \\ Correspondence: Hafnida Hafnida, Islamic Business School, Economics Building, Universiti Utara Malaysia, \\ Malaysia. E-mail: hafnida@gmail.com
}

Received: March 30, 2015

Accepted: April 24, 2015

Online Published: June 20, 2015

doi:10.5539/ijbm.v10n7p93

URL: http://dx.doi.org/10.5539/ijbm.v10n7p93

\begin{abstract}
Islamic modes of finance become new phenomenon in financial system. Islamic modes of finance are designed to facilitate financing by the principles in Islamic Sharia, such as muḍārabah, mushāraka and sukuk. In addition financial intermediation is an important indicator of economic development as well as economic growth. The objective of this study is to determine the relationship between Islamic modes of finance and Islamic financial intermediation by using case study of Malaysia, Indonesia and Jordan. This study employed fixed effect and random effect through time series data from 2001-2010 for both Malaysia and Indonesia. Liquid liabilities, private sector credit and Islamic modes of finance such as muḍārabah, mushārakah, murābaḥa, 'istiṣnā, 'ijārah used as independent variables that expected to be influence Islamic financial intermediation as well as economic growth. Findings show that Islamic mode of finance which include murābaha, mushārakah, muḍārabah, 'istiṣnā, ijārah. While, private sector credit as well as liquid liabilities are not affect Islamic financial intermediation.
\end{abstract}

Keywords: Islamic modes of finance, financial intermediation, liquid liabilities, private sector credit, fixed and random effect

\section{Introduction}

Islamic finance has now gained recognize in the global financial system. According to Haron and Ahmad (2000), Islamic banks have been showing considerable progress since the first Islamic bank in Egypt which was established in 1963. Since then, the number of Islamic banks has increased rapidly. The concept of Islamic banking is essentially based on prohibition of interest (riba). Hussain, Abdullah, and Shaari (2013) asserted that Islamic banking is based on banking Islamic law (Sharia) by using fiqh muamalat, which adopted from Quran and the Sunnah and other secondary sources of Islamic law. The first Islamic bank based on Sharia is Mit Ghamr Bank, which success to provide savings and credit needs for customer. It was surprised to the whole of the economic and Islamic scholars. Zin et al. (2011) stated that in contributing to economic development, Islamic finance industry can use as one of tool in competitive and comprehensive market consistency through conventional financial system. Since then, the establishment of Islamic bank growing faster particularly in Islamic countries.

In the early stages of a financial crisis 2008 was considered to be the worst in the post war period. Based on existing literature, speculative bubbles underline three main ingredients (Chancellor, 1999; Eichengreen \& Mitchener, 2003; Kindleberger \& Aliber, 2005; IMF, 2008; Turner, 2009). First, there is abundant liquidity in the world capital markets, fed by large payment imbalances between the main countries and regions in the world economy; for example, the deficit in the United States financed by ample flows of capital from emerging and oil-exporting countries. Second is a credit boom leading to unsustainable leverage (Eichengreen \& Mitchener, 2003). The crisis was caused by a combination of asset price and credit bubble that led to excessive leverage. For a country leverage is better defined as the ratio of credit outstanding to GDP. Higher aggregate leverage generally indicates less capacity to absorb losses. Within by small reductions in debt achieved in the private sector has been more than compensated by the fall in GDP. Lastly ingredient is financial innovation, which is the process of securitization (Mandelbrot \& Hudson, 2004; IMF, 2008; Turner, 2009). Securitization as a greater tendency toward market determined interest rates and marketable financial instruments rather than bank loans. Securitization and the increased use of financial intermediaries will burden of credit evaluation and the increase in market linkages itself will be seen as a sources of added risk. 
Since that crisis 2008 , as stated by Turner (2009) that financial intermediation started grows much more rapidly starting in 2003. Banks became interconnected with a complicated web of financing, investment and hedging operations, it will be difficult to assess attendant risks independently. Tabash and Dhankar (2014) showed that the situation represented the wake of credit crunched and subsequent banking crisis. The present crisis has already slowed down economic growth in many industrial countries, increased unemployment, extraordinary of fiscal costs and made instability of finance. Beck et al. (2013) stated that Islamic banking give attention when financial crises increased. This finance could prevent a new crisis (Pastre \& Jouini, 2009; Saidane, 2010) and in addition by Hassan (2009) that finance help to control discipline, transparency and expect for stability. Khaldi and Hamdouni (2011) explained that, surprisingly, the phenomenon of Islamic finance has developed quickly in the United States and Europe, even though it is still very concentrated in the Middle East and South-east Asia.

However, since the mid twentieth-century, Levine (1997) discussed the role of well-functioning financial intermediation in helping creative entrepreneurs with innovative ideas find funding and thereby contribute to increased productivity and economic growth. According to Tabash and Dhankar (2014) that with global markets suffering from extreme turbulence in the wake of the credit crunch and subsequent banking crisis, it is the time to examine the merits of an alternative banking model which adopts a different attitude to risk and finance, based on the principles of Sharia. Siddiqi (1983) stated that Islamic banks have been constructed as financial intermediaries which mobilize resources in the direction of shariah approved projects by using Islamic financing instruments. It supported by Iqbal and Ahmad (2005) that the efficient and viable method of financial intermediation which used Islamic banking. The Islamic financial intermediations are muḍārabah, mushārakah, 'murābaḥa', 'istișnā', 'ijārah'. In addition, El Qorci (2005) noted that in Islamic financial intermediation, investment risk is considered to be the most critical operational risk affecting the PLS (Profit Loss Sharing) activities of Islamic banks. In addition, Yusof and Bahlous (2013) asserted that Islamic finance is a very particular mode of financial intermediation that companies could benefit from as the fund provider participates in the profits and loss of the project. Therefore, financial intermediation by using PLS is effective way and competitive to increase growth.

The recent impact of global financial crisis in 2008 has brought to the surface of variety issues concerning the stability and soundness of the conventional financial system. After that, the OIC member countries started to implement Islamic modes of financing as their economy system. Even that, many still argues that Islamic modes of finance product had been limited generally on development process and it re-engineering of the conventional products by using Sharia requirement. Therefore, the objective of this study is to determine the relationship between Islamic modes of finance and Islamic financial intermediation. The paper is structured by dividing them into four parts. Firstly, it will discuss mainly about previous research on similar issue. Then, will provide model specification, followed by a discussion on the estimation result. The last is concluding remarks.

\section{Literature Review}

As we know, the existence of Islamic banking and finance can help us avoiding crisis. This was seen in the financial crisis in 2008, Islamic finance played the role of financial intermediary, prevent a crisis and create stable economy; thus, promoting economic growth. Iqbal and Ahmad (2005) noted that the idea of Islamic financial intermediation exist with the real scope. This is supported by Saidane (2010), who found that with interest rate based system is frequently losses and repetitive crisis, while Islamic financial intermediation is an anti-crisis intermediation. Zarqa (1997) explained that 'istișnā' is a tool for financial intermediation for the contractor in the subcontract. As stated by Rosly (2005) and Al-Amine (2001) that one of Islamic modes of finance can be used to finance manufacturing of products is 'istișnā. In a sale contract, manufacturer responsible in distribute goods to buyer at a future date (based on agreement), even with exchange for an advance price fully or paid on the exactly time partially.

Meanwhile Ahmed (2005) described that muḍārabah and mushārakah are especially important account as financing social projects by commercial banks and it related with majority people who was living in rural Bangladesh. In addition, Khoutem and Nedra (2012) found that Islamic intermediation, includes 'muḍārabah' and 'mushārakah', which can promote economic growth. Farooq and Ahmed (2013) explained that, nowadays, murābaḥa and 'ijārah' play a major role in Islamic banking.

As empirically by using PLS, Ahmad et al. (1998) showed that the average of PLS of total financing in the Islamic banking industry was $17.34 \%$ during 1994-1996. Khan and Bhatti (2008) explained that the average for PLS instruments (muḍārbah and mushārakah) was 6.34\% during 2004-2006. In addition, Cihak and Hesse (2010) found significant differences in the z-scores of conventional and Islamic banks using data from 18 countries for the period 1993-2004 in respect of PLS financing. Therefore, large number of products is available in Islamic 
finance, and the number is growing as demand for more Islamic compliant products grow throughout the world. Islamic modes of finance have important role as Islamic financial intermediation through with the economic system.

\section{Methodology and Data Collection}

In order to assess the effect of Islamic modes of finance, liquid liabilities and private sector credit on Islamic Financial Intermediation into Indonesia, Jordan, and Malaysia, we conduct a regression analysis. Meanwhile, for year 2001-2010, by considering the small number of time series data, this study proceeds by using panel data, pooling three countries that have been mentioned above. The following general specification of panel data has been followed Abdullah et al. (2014) by using fixed effect and random effect models:

$$
F I_{i t}=\beta_{0}+\sum_{i=1}^{n} \beta_{1} I M F_{i t}+\beta_{3} L L_{i t}+\beta_{4} P C_{i t}+\varepsilon_{i t}
$$

where, FI is financial intermediation, IMF is Islamic mode of finance consist of 'muḍārabah', 'mushārakah', 'murābaḥa', 'istișnā', and 'ijārah'. LL is a liquid liabilities and PC is a private sector credit. $\beta$ i ( $\mathrm{i}=1,2$, and 3) are parameter of equation, and . $\varepsilon_{-}$it is a white noise disturbance term.

This study uses secondary data which collected from World Bank, Global Development Finance and Islamic Finance Directory.

\section{Findings}

The discussion of this section will be divided into two part, descriptive analysis and result of fixed and random effect. The descriptive statistics analysis to define the characteristics of the data use in this study can be referred in Table 1.

Table 1. Descriptive analysis of variables used $(\mathrm{N}=30)$

\begin{tabular}{lllll}
\hline Variable & Mean & Std. Dev & Min & Max \\
\hline Islamic Financial intermediation (USD’000) & 4.178 & 0.187 & 3.325 & 4.349 \\
Murābaha(USD’000) & 2.599 & 0.061 & 2.360 & 2.695 \\
Mushārakah(USD’000) & 2.213 & 0.613 & 0 & 2.634 \\
Mud̄ārabah(USD’000) & 2.262 & 0.214 & 1.662 & 2.589 \\
‘ijārah(USD’000) & 2.240 & 0.659 & 0 & 2.651 \\
‘istișnā(USD’000) & 2.007 & 0.818 & 0 & 2.564 \\
Private sector credit (\% from GDP) & 4.069 & 0.705 & 2.844 & 4.849 \\
Liquid liabilities (\% from GDP) & 4.427 & 0.527 & 3.576 & 4.871 \\
\hline
\end{tabular}

As indicated in Table 1, for example the mean value of 'murābaha' for 30 observations was 2.599 with standard deviation .0613 , minimum and maximum values of 2.360 and 2.695 respectively. The positive on 'murabahah' indicates that the variable will influence the financial intermediation. Meanwhile, 'musharakah' had a mean value of 2.213 with standard deviation .613 and the value of minimum and maximum around 0 and 2.634 respectively. This observation indicates that useless of 'musharakah' in term effect to financial intermediation. These results suggest that banks will distribute more 'musharakah' as one of benefit financing. The maximum value of 2.634 however indicates that there were some banks working with capital management policy by holding high levels of 'musharakah' in financial system.

The following discussion is regarding relationship between Islamic financial intermediation and selected variables by using fixed effect model and random effect model (see Table 2). 
Table 2. Result of fixed effect and random effect

\begin{tabular}{lll}
\hline Variables & Fixed Effects Model & Random Effects Model \\
\hline Murābahạa & $1.011^{* * *(7.84)}$ & $1.073 * * *(6.75)$ \\
Mushārakah & $0.081 * * *(9.90)$ & $0.079 * * *(8.10)$ \\
Muḍārabah & $0.112^{* *}(2.33)$ & $0.079(1.37)$ \\
'Ijārah & $0.069 * * *(5.37)$ & $0.060 * * *(4.35)$ \\
'Istișnā & $0.089 * * *(11.40)$ & $0.103 * * *(13.60)$ \\
Private Sector Credit & $-0.002(-0.10)$ & $0.001(0.05)$ \\
Liquid Liabilities & $0.002(0.03)$ & $-0.024(-0.84)$ \\
Constant & $0.503(0.99)$ & $0.238(0.58)$ \\
\hline F Test & $6.83[0.0058]$ & \\
LM Test & & $0.46[0.4971]$ \\
Hausman Test & $20.06[0.0101]$ & \\
R-squared & 0.9814 & 0.9890 \\
Notes. $* * *$ indicates significant at $1 \%, * *$ indicates significant at $5 \%$, and $*$ indicates significant at $10 \% ;$ t-statistics are in parentheses.
\end{tabular}

Table 2 shows the result of fixed and random effect of Islamic financial intermediation. The Hausaman test in fixed effect shows that this model was significant and not correlated regressors. This suggest that the fixed effect is appropriate as model in this study than random effects model. Therefore, the discussion later on will be focused on the fixed effect model since it is a chosen model in this study.

The results show that an increase in murābaha causes an increase in financial intermediation of selected countries. As expected, the coefficient for this variable is positive by 1.011 and statistically significant at $1 \%$ level. This result is also in line with the previous literature on Islamic financial intermediation.

The mushārakah variable has positive coefficient 0.081 and statistically significant at $1 \%$ level, implying that it has impact on Islamic financial intermediation. Meanwhile, for mudāarabah is typically positive coefficient by 0.112 and statistically significant at 5\% level. We can conclude that by using Profit Loss Sharing, two of this variable will influence the Islamic financial intermediation.

Istișnā and financial intermediation are correlated significantly and positively with each other. The coefficient is 0.089 and statistically significant at $1 \%$ level. It indicates that 'istișnā' is fairly effective for Islamic financial intermediation. The result also shows that 'ijārah' is positive sign coefficient by 0.069 and strongly significant at $1 \%$ level. This reflects that countries with large Islamic financial intermediation have more good demand of Islamic modes of finance.

The private sector credit shows that they have negative effect on Islamic financial intermediation with the number coefficient of -0.002 and not significant. It indicates that this variable may hide the fact that private sector credit not effect financial intermediation. In addition, for liquid liabilities in the fixed effects model, it has positive effect but not significant with coefficient number 0.0018 respectively. It is supported by previous study that liquid liabilities have positive effect on other measures of financial development. (e.g. Favara, 2003; Demetriades \& Law, 2006; Ahlin \& Pang, 2008). Besides that, the goodness of fit reflected by the R-square shows that for overall variable will give effect to financial intermediation around $98 \%$.

\section{Discussions and Conclusions}

In this study, we used Islamic modes of finance, which include muḍārabah, mushārakah, murābaha, 'istiṣnā, 'ijārah', private sector credit and liquid liabilities as variables which will affect Islamic financial intermediation. The data was a secondary data from 2001-2010 in three countries namely, Indonesia, Jordan and Malaysia. In general, the findings show that Islamic modes of finance positively and significantly affect Islamic financial intermediation. On the other hand, for liquid liability, it has positive effect but not significant and for private sector credit, it has no direct correlation with financial intermediation.

The first positive relationship exists between Islamic modes of finance and Islamic financial intermediation, means that if the number of Islamic modes finance increase, it will increase Islamic financial intermediation. It causes Islamic modes of finance to be one of the tools that can be used in financial intermediation.

Another positive relationship was found between liquid liabilities and Islamic financial intermediation even though it is not significant. When the bank increases the number of liquid liabilities, it will increase financial intermediation. Meanwhile, private sector credit and Islamic financial intermediation have a negative 
relationship. It is inconsistent with the previous study that private sector credit which have positive effect on financial intermediation. Means that when the bank distribute credit to private sector as a finance, it will not continue grow up for financial intermediation at the same time. Its shows that the Islamic mode of finance is still not a choice as compared to other mode of finance. There is room to improve for Islamic mode of finance to be one the chosen finance in a country especially for the OIC countries to ensure that it will be accepted and later increase the financial intermediation as well as economic growth.

\section{References}

Abdullah, N., Abdullah, H., \& Othman Abuhriba, H. M. (2014). The determinants of trade and trade direction of Arab Maghreb Union (AMU). Journal of Empirical Economics, 2(2), 46-62.

Ahlin, C., \& Pang, J. (2008). Are financial development and corruption control substitutes in promoting growth? Journal of Development Economics, 86(2), 414-433. http://dx.doi.org/10.1016/j.jdeveco.2007.07.002

Ahmad, A., Khan, T., \& Iqbal, M. (1998). Challenges Facing Islamic Banking. Islamic Research and Training Institute, Jeddah.

Ahmed, H. (2005). The Islamic financial system and economic growth: An assessment. In M. Iqbal \& A. Ahmad (Eds.), Islamic finance and economic development. New York: Palgrave Macmillan.

Al-Amine, M. A. B. (2001). Istisna' in Islamic Banking and Finance: Law \& Practice. Kuala Lumpur: ASN Publishing.

Beck, T., Demirgüç-Kunt, A., \& Merrouche, O. (2013). Islamic vs. conventional banking: Business model, efficiency and stability. Journal of Banking \& Finance, 37(2), 433-447. http://dx.doi.org/10.1016/j.jbankfin.2012.09.016

Chancellor, E. (1999). Devil Take the Hindmost: A History of Financial Speculation. Basingstoke: Macmillan.

Čihák, M., \& Hesse, H. (2010). Islamic banks and financial stability: An empirical analysis. Journal of Financial Services Research, 38(2-3), 95-113. http://dx.doi.org/10.1007/s10693-010-0089-0

Demetriades, P., \& Law, S. H. (2006). Finance, institutions and economic development. International Journal of Finance and Economics, 11(3), 245-260. http://dx.doi.org/10.1002/ijfe.296

Eichengreen, B., \& Mitchener, K. (2003). The Great Depression as a Credit Boom Gone Wrong. BIS Working Paper 137.

El Qorchi, M. (2005). Islamic finance gears up. Finance and Development, 42(4), 46.

Farooq, M., \& Ahmed, M. M. M. (2013). Musharakah Financing: Experience of Pakistani Banks. World Applied Sciences Journal, 21(2), 181-189. http://dx.doi.org/10.5829/idosi.wasj.2013.21.2.2387

Favara, G. (2003). An empirical reassessment of the relationship between finance and growth. In Working Paper No. 03/123. Washington: International Monetary Fund.

Haron, S., \& Ahmad, N. (2000). The effects of conventional interest rates and rate of profit on funds deposited with Islamic banking system in Malaysia. International Journal of Islamic Financial Services, 1(4), 1-7.

Hassan, A. (2009). The global financial crisis and Islamic banking. Retrieved from http://www.islamic-foundation.org.uk/IslamicEconomicsPDF/Hassan-financialcrisis-if.pdf

Hussain, N. E., Abdullah, H., \& Shaari, M. S. (2013). Efficiency and profitability of Islamic banking in Malaysia. Journal of Applied Sciences Research, 8(11), 5226-5241.

International Monetary Fund. (2008). Global Financial Stability Report, April. Washington, DC: IMF.

Iqbal, M., \& Ahmad, A. (2005). Islamic Finance and Economic Development. New York: Palgrave Macmillan.

Khaldi, K., \& Hamdouni, A. (2011). Islamic financial intermediation: equity, efficiency and risk. International Research Journal of Finance and Economics, 65, 145-160.

Khan, M. M., \& Bhatti, I. M. (2008). Development in Islamic banking: a financial risk-allocation approach. The Journal of Risk Finance, 9(1), 40-51. http://dx.doi.org/10.1108/15265940810842401

Khoutem, B. J., \& Nedra, B. A. (2012). Islamic participative financial intermediation and economic growth. Journal of Islamic Economics, Banking and Finance, 3(8), 44-59.

Kindleberger, C. P., \& Aliber, R. (2005). Manias, Panics, and Crashes: A History of Financial Crises. Hoboken, NJ: John Wiley and Sons. 
Levine, R. (1997). Financial development and economic growth: Views and agenda. Journal of Economic Literature, 688-726.

Mandelbrot, B., \& Hudson, R. L. (2004). The (Mis) Behavior of Markets: A Fractal View of Risk, Ruin and Reward. New York: Basic Book.

Pastré, O., \& Jouini, E. (2009). La finance islamique: Une solution à la crise? (No. 123456789/1744). Paris Dauphine University.

Rosly, S. A. (2005). Critical issues on Islamic Banking and financial markets. Malaysia: Dinamas Publishing.

Saidane, D. (2010, April). La finance islamique: une finance libred'interet. Colloque Finance islamique: realiteset perspectives, Tunis.

Siddiqi, M. N. (1983). Issues in Islamic banking. The Islamic Foundation, Leicester.

Tabash, M. I., \& Dhankar, R. S. (2014). The flow of Islamic finance and economic growth: An empirical evidence of Middle East. Finance and Accounting, 2(1), 11-19. http://dx.doi.org/10.11648/j.jfa.20140201.12

Turner, A. (2009). The Turner Review: A regulatory response to the global banking crisis (Vol. 7). London: Financial Services Authority.

Yusof, R. M., \& Bahlous, M. (2013). Islamic banking and economic growth in GCC \& East Asia countries: A panel cointegration analysis. Journal of Islamic Accounting and Business Research, 4(2), 151-172. http://dx.doi.org/10.1108/JIABR-07-2012-0044

Zarqa, A. M. (1997). Istișnā financing of infrastructure projects. Islamic Economic Studies, 4(2).

Zin, M. Z. M., Ishak, S., Kadir, A. R. A., \& Latif, M. S. A. (2011). Growth and Prospect of Islamic Finance in Malaysia. International Proceedings of Economics Development \& Research, 5(1).

\section{Copyrights}

Copyright for this article is retained by the author(s), with first publication rights granted to the journal.

This is an open-access article distributed under the terms and conditions of the Creative Commons Attribution license (http://creativecommons.org/licenses/by/3.0/). 